IRA-International Journal of Education \& Multidisciplinary Studies

ISSN 2455-2526; Vol.12, Issue o3 (September, 2018)

Pg. no. 61-73

Institute of Research Advances

http://research-advances.org/index.php/IJEMS

\title{
Reading Metacognitive Strategies Employed by ESL Learners
}

\author{
Noor Zainab Abdul Razak ${ }^{1 \#}$, Nur Ashikinbinti Abdul Gani ${ }^{2}$ \& Nur Hazirah Che Ithnin ${ }^{3}$ \\ 1,2,3 Universiti Teknologi Malaysia, Johor, Malaysia. \\ \#corresponding author. \\ Type of Review: Peer Reviewed. \\ DOl: http://dx.doi.org/10.21013/jems.v12.n3.p2

How to cite this paper:
Razak, N.Z.A., Gani, N.A.A., Ithnin, N.H.C. (2018). Reading Metacognitive Strategies Employed by ESL
Learners. IRA International Journal of Education and Multidisciplinary Studies (ISSN 2455-2526), 12(3),
61-73.doi: http://dx.doi.org/10.21013/jems.V12.n3.p2

(c) Institute of Research Advances.

\section{(cc) EY-NC}

This work is licensed under a Creative Commons Attribution-Non Commercial 4.0 International License subject to proper citation to the publication source of the work.

Disclaimer: The scholarly papers as reviewed and published by the Institute of Research Advances (IRA) are the views and opinions of their respective authors and are not the views or opinions of the IRA. The IRA disclaims of any harm or loss caused due to the published content to any party.

Institute of Research Advances is an institutional publisher member of Publishers Inter Linking Association Inc. (PILA-CrossRef), USA. The institute is an institutional signatory to the Budapest Open Access Initiative, Hungary advocating the open access of scientific and scholarly knowledge. The Institute is a registered content provider under Open Access Initiative Protocol for Metadata Harvesting (OAI-PMH).

The journal is indexed \& included in WorldCat Discovery Service (USA), CrossRef Metadata Search (USA), WorldCat (USA), OCLC (USA), Open J-Gate (India), EZB (Germany) Scilit (Switzerland), Airiti (China), Bielefeld Academic Search Engine (BASE) of Bielefeld University, Germany, PKP Index of Simon Fraser University, Canada. 


\begin{abstract}
This study aims to investigate the relationship between the metacognitive reading strategies employed by the ESL learners in a secondary school in Malaysia and their English proficiency. The objective of this study is to identify the types of metacognitive strategies employed by students while reading academic text. In addition, this study also aims to investigate the differences (if any) in metacognitive strategies employed by the high and low English proficiency students while reading academic text. The respondents of this research are forty students with high and low English proficiency and were selected randomly. This study is using the quantitative research method where questionnaire is used to obtain the data. Metacognitive Awareness of Reading Strategies Inventory (MARSI) was used as the measuring tools to identify the metacognitive reading strategies employed by the students. The result of this study shows that the students employed the three metacognitive strategies which are Global Reading Strategies (GLOB), Supporting Reading Strategies (SUP) and Problem-Solving Reading Strategies (PROB). In addition, the mostly employed metacognitive reading strategy was Global Reading Strategies (GLOB), followed by Supporting Reading Strategies (SUP) and Problem-Solving Reading Strategies (PROB). As a conclusion, metacognitive reading strategies can be implemented by secondary school English language teachers in their teaching as it beneficial in helping learners' comprehension.
\end{abstract}

Keywords: language proficiency, Metacognitive Awareness of Reading Strategies Inventory (MARSI), metacognitive reading strategies, reading strategies, secondary school

\title{
Introduction
}

In Malaysia, generally, English is officially described as the second language and spoken throughout the country. English is one of the core subjects in the Malaysian education system, starting from primary level (Year 1 to Year 6) and secondary level (Form 1 to Form 5). Majority of these students will further their studies in the tertiary education and English language is a prerequisite if they want to be successful in their academic endeavour. Thus, it is essential for one to be able to master the four macro skills, namely listening, speaking, reading and writing at an early stage. Reading skills are given more emphasis as pupils need to undergo several examinations throughout the primary and secondary school year. In addition, most tests contain reading components and students need to have good reading comprehension skills to do well in examinations.

However, it is crucial to note that this position depends upon the fact that it is taught from the first year of primary school. In addition, this particular status had made English as the medium of instruction in many schools and most tertiary institutions. Therefore, teaching and learning of English language in schools has become a major concern. Many scholars came up with teaching strategies and pedagogical implication for teaching ESL and it includes the language learning strategies among ESL learners.

The Language Learning Strategies (LLS) consists of subcategories of strategies which are direct and indirect strategies. Metacognitive strategies are one of the direct strategies that can be employed in acquiring knowledge of English especially in reading comprehension. Metacognitive strategies are used in organising the overall learning process. They include a lot of stages from the preparation of the learning such as identification of individual's own learning style preferences and needs, plan for an L2 task, gathering and organisation of materials, and arrangement of a study space and a schedule, while learning such as monitoring mistakes, as well as to evaluation phase such as evaluation of task success, and evaluation of the success of any type of learning strategy. Hence, a study is carried out to investigate the metacognitive strategies employed by the ESL learners in secondary schools while comprehending academic text.

Reading comprehension is imperative in acquiring the language and to obtain information. Nevertheless, many language learners are not aware of how the language learning strategies that they employed when reading an academic text affect their comprehension of the academic text (Hadavi\&Hashemi, 2014). In addition, most of the second language learners find difficulties in order to comprehend reading materials without employing certain strategies to comprehend the text (Anderson, 1999). Furthermore, many researches have proven that skilled learners mostly employed metacognitive strategies while reading compared to unskilled learners (Mokhtari\&Reichard, 2002).

Due to the students' unawareness of how metacognitive strategies can help their reading comprehension, this research intends to investigate metacognitive strategies employment among ESL secondary school student in 
Malaysia. Therefore, this study was carried out to find out the types of metacognitive strategies employed by high and low English proficiency secondary school students while reading in their ESL classroom. Furthermore, this study is also aimed to examine the most frequently employed metacognitive strategies and investigate if there is any significant difference of the metacognitive strategies employed between the high and low English proficiency students in comprehending academic text.

This study was carried out to create awareness of language learning strategies employed by secondary school students in ESL classroom. According to Chamot (2004), a good language learner will employ metacognitive knowledge to think about their thinking and carry out the strategies that suit them best. Therefore, learners are encouraged to employ metacognitive strategies to achieve a successful learning. This study will also provide the teachers with information about the students' metacognitive strategies employed while reading academic text in ESL classroom. Thus, this study is significant for the teachers to know the metacognitive strategies that are employed by students when reading academic text so that they can increase the awareness of metacognitive strategies employed while reading academic text. According to Mokhtari and Reichard (2002), it was proven by many researchers that metacognitive awareness in reading comprehension differentiates the skilled learners from the unskilled learner. Therefore, the findings are hoped to help teachers to incorporate explicit teaching and implicit use of these strategies into everyday classroom activities.

\section{Scope of Study}

The scope of the study consists of secondary school students from secondary school in Johor. Respondents selected for this study are 40 Form 4 students who are learning English as Second Language. The students chosen will be categorized into two groups namely the low English proficiency students and the high English proficiency students. In this study, the Form 4 students are chosen as the respondents because they are currently preparing for the SPM examination and they are required to read academic text to answer the comprehension question during examination. Therefore, they are chosen to see what types of metacognitive strategies employed by these students for their reading comprehension.

\section{Language Learning Strategies}

According to Oxford (1989), language learning strategies are behaviors or actions which learners use to make language learning more successful, self-directed and enjoyable. On the other hand, Stern (1983), also noted that learning outcomes are much influenced by learning process, and the learning process is affected by the learners' internal characteristics and learning conditions. Therefore, the studies on language learning strategies evidently prove a great significance. Studies suggest that language learners employ certain ways to learn a language and are capable of becoming aware of their mental processes, which are their metacognitive. In addition, majority of the weak learners are weak in their use of metacognitive strategies although these strategies drive students to success' (Mazumder, 2010). Thus, learners are encouraged to apply metacognitive skills to improve their language performance in developing their speaking skills in the English language as they aid students to plan organize, practice and evaluate their learning especially towards lifelong learning (Saemah\&Sa'diah, 2010).

Oxford (1990) identified the different factors that affect the choice of strategies: degree of awareness, stage of learning, task requirements, teacher expectations, age, sex, nationality or ethnicity, general leaning style, personality traits, motivation level and purpose for learning the language. Oxford also developed a taxonomy which divides language strategies into twomain groups: direct and indirect strategies. Language learning strategies that indirectly involve the target language are called direct strategies. Strategies that support the language learning process are called indirect strategies namely metacognitive, affective and social strategies. This study will focus on the metacognitive strategies employed by the second language learners in secondary schools.

\section{Reading Strategies in ESL Classroom}

Reading strategies are the mental processes used by readers to approach the text and try to make sense of what they are reading (Al-Dawaidah\& Al-Saadi, 2013). Reading strategies also suggest how readers view 
interaction with written text and how strategies are related to text comprehension (Imtiaz, 2004). Reading strategies reveal ways in which readers manage to interact with written texts and how strategies are related to text comprehension. They also involve skimming, scanning, contextual guessing, critical reading, inferencing and recognizing text structure (Imtiaz, 2004). Reading is a necessary skill for a successful academic learning, and it is the most important skill for second language learners to master the language in academic context(Grabe, 1991). Reading is defined as psycholinguistic processes that construct meaning for readers through interaction with the text as what the writer intended to deliver (Goodman, 1994).

In certain studies of descriptive nature, think-aloud has been used to view the difference between reading strategies among successful and unsuccessful reader. The differences between successful and less successful readers was in the following aspects namely integration, recognition of aspects of text structure, use of general knowledge, personal experiences and associations, and response in extensive vs. reflexive modes (Block, 1986). For the case of extensive mode, readers will try to deal with the message delivered by the author and focus more on the author's ideas rather than relating the text to themselves personally or affectively. On the other hand, for the case of intensive mode, readers will relate the text while focusing on their own feelings and thoughts more than the information in the text.

The division of readers into a hierarchy of integrators and non-integrators showed that the successful readers integrated information and were aware of text structure, while the less successful readers failed to integrate and tended not to recognize text structure (Block, 1986). This shows that reading strategies employed by students will affect students' understanding and learning process. Students read effectively when they frequently apply more strategies (Pani, 2004). There are certain characteristics of efficient and inefficient readers (Paris \& Jacobs, 1984). Efficient readers typically used self-monitoring strategy such as contemplating the title, looking to top and bottom of a passage and ask themselves whether or not they understand what they have read. On the other hand, inefficient readers or beginner do not apply these skills, while efficient readers frequently use cognitive strategies than inefficient readers (Anastasiou\&Griva, 2009).

\section{Metacognitive Strategies}

Metacognitive strategies go beyond the cognitive mechanism and give learners to coordinate their learning (Imtiaz, 2004). This helps them to plan language learning in an efficient way. When new vocabulary, rules, and writing system confuse the learners, these strategies become vital for successful language learning. Metacognition enables and helps learners to become successful learners, and has been associated with intelligence. Students who use metacognitive strategies will perform better in examination and complete work more effectively (Onovughe\& Hannah, 2011). 'Metacognitive knowledge' is defined as "consisting primarily of an understanding or perception of the ways in which different factors act and interact to affect the course and outcome of cognitive enterprise" (Flavell, 1979). In other words, metacognition is the knowledge that a person has of his or her own cognitive processes. There are three major factors that have been identified, which are person, task and strategy (Flavell, 1979). Factors like age, aptitude, learning styles affects the person knowledge as well (Wenden, 1991). 'Person knowledge' also includes what learners know about themselves as learners, and the beliefs that they have about what leads to their success or failure in language learning; knowledge that the learners have about the purpose, demands and nature of learning tasks are, therefore, included in 'task knowledge' (Wenden, 1991). It also includes the knowledge of the procedure that learners have. In other words, it includes learners understanding of which approach of language learning is best for them.

Metacognitive strategies involved selective attention, planning for organization and monitoring comprehension (Imtiaz, 2004). The aim of involving selective attention is to give a focus to the learners so that the attention could be directed toward certain language activities or skills. Planning for organization will help learners to organize so they may get maximum benefit from their energy and effort. Monitoring comprehension helps learners with problems like monitoring errors and evaluation of progress. Metacognitive strategies involve planning, monitoring and evaluation that take place before, during and after any thinking act, for instance, reading (Anastasiou\&Griva, 2009). 


\section{Previous Study of Metacognitive Strategies in Reading}

Many researches have been done regarding metacognitive strategies in reading comprehension. Reading for comprehension involves a great deal of cognitive capacity (Pressley, 2002). For instance, good readers know that reading activities will lead to comprehension. A good learners or readers will be able to relate the information from the reading materials with their prior knowledge and summarize what have been read. These strategies are metacognitive concepts in reading (Pressley, 2002). Studies on reading have evidently validated that there is a positive relationship between learners' reading processes and their ability to understand the text that they are reading (Al-Dawaidan\& Al-Saadi, 2013). Students that are lack of vocabulary and decoding ability find reading comprehension challenging, however, this could be due to insufficient strategic knowledge (Gardner, 1987).

Another study also demonstrated that the awareness and monitoring of a leaner's comprehension processes are critical aspects of skilled reading (Mokhtari\&Reichard, 2002). Apart from that, another study investigated on the relationship between reading strategy and reading comprehension among Indian ESL learners as the learners mostly preferred to apply problem solving strategy while reading, followed by supporting strategies and global strategies (Madhumati\& Gosh, 2012). Thus, it is evident that relationship between reading strategies and reading comprehension achievement exists. In addition, gender differences in strategy used is evident when female students seemed to exhibit superior performance compared to male students.

The number of factors that influence reading abilities will increase when reading is done in a second language (Block, 1992). For instance, the studies of reading strategies used by Chinese native speakers when they read in English (Feng \&Mokhtari, 1998) and (Kong, 1998) have proven that readers used more strategies when reading in English than in Chinese. The same results were also found among the Dutch high school students (Stevenson,Schoonen\&Glopper, 2003). Apart from that, a study investigating the differences of reading strategies used by native and non-native readers when reading academic materials was carried out (Sheorey\&Mokhtari, 2001). The results of the study found that both native and non-native readers show awareness of nearly 30 targeted strategies and display the same order of importance to the type of reading strategies used regardless of their reading abilities. Readers gave more importance to Problem Solving strategies than Global Reading strategies and the least is Support Reading strategies (Sheorey\&Mokhtari, 2001).

"Strategies are especially important for language learning because they are tools for active, self-directed involvement, which is essential for developing communicative competence," (Oxford, 1990). Thus, it is acknowledged that an understanding and awareness of learner strategies on the part of both teacher and students may provide valuable insights into the process of language learning. This, in turn, may enable individual learners to adopt or further develop a range of effective language learning strategies, and may encourage teachers to incorporate their active use in regular class.

In addition, another study demonstrated that the cognitive and metacognitive strategies were employed more frequently for first-language reading and support strategies were more often used for second language reading (Yau, 2009). This shows that learners have not yet fully employed the metacognitive strategies in reading second language materials. By understanding the metacognitive strategies while reading academic materials in ESL classroom, learners' potential for a successful reading comprehension can be maximized.

On the other hand, there are three metacognitive reading strategies in reading academic text, namely Global Reading Strategies, Problem Solving Strategies and Support Reading Strategies (Mokhtari\&Sheorey, 2002).

The Global Reading Strategies (GLOB) aimed at setting the stage for the reading act. The strategies are read with a purpose in mind, think about what reader know to help reader understand what is read (pre-information), over all view of the text to see what it's about before reading, decide whether the content of the text fits the reading purpose and review the text first by noting characteristics including length and organization. Other strategies also include the reader when reading to decide what to read closely and what to ignore, use tables, figures, and pictures in the text to increase understanding, use context clues to help better understand the reading, use typographical features like bold face and italics to identify key features. In addition, learners are also asked whether they critically analyze and evaluate the information presented in the text, check understanding when coming across new information, guess what the content of the text is about when reading and check to see if guesses about the text are correct. 
The Problem Solving Strategies (PROB) is the strategies used when readers encounter problems in understanding textual information. The strategies are to read slowly and carefully to make sure the reader understand what the reader is reading, try to get back on track when distracted or lose concentration, adjust reading speed according to the reading material, pay closer attention to the material when text becomes difficult and stop from time to time and think about the reading. Other strategies are trying to picture or visualize information to assist in remembering, re-read to increase understanding when text becomes difficult, and guess the meaning of unknown words or phrases when reading,

The Support Reading Strategies (SUP) use the support mechanisms aimed to sustain readers' responsiveness to reading. The strategies consist of taking notes while reading to assist in understanding, when text becomes difficult, read aloud to assist in understanding, summarizing to reflect important information in the text, discussing with others to check reader's understanding, underline or mark-up information in the text to assist in remembering, use reference materials (dictionaries, etc.), paraphrase/restate to better understand, go back and forth in the text to find relationships among ideas and finally, asking themselves questions to find answers in the text.

This 30-item questionnaire was validated by using large subject population, ranging from secondary level to tertiary level, which represents students with the corresponding reading abilities (Mokhtari\&Reichard, 2002). The results show that the questionnaire can be used as a realistic and reliable measure of metacognitive awareness of reading strategies.

\section{Respondents of the Study}

The respondents selected for this study were 40 Form 4 students from a secondary school in Malaysia. All of these students are the second language learners of English and had taken their Form 3 Malaysian public examination. In all Malaysian government aided schools, students must sit for a lower secondary public examination when they are in their Form 3 and another public examination in their Form 5. All the examinations were set and examined by the Malaysian Examinations Syndicate, an agency under the Ministry of Education.This research aimed not to choose students who were in their examination year, thus selecting Form 4 students, who had sat for the lower secondary public examination. The English language results from this examination will be used to determine the proficiency level of the respondents in this research. Twenty students who obtained grade A and twenty students of grade D were randomly selected to participate in this research.

\section{Research Design of the Study}

The purpose of this study was to identify the most frequently metacognitive strategies employed by secondary school students while reading in ESL classroom. This study also aims to identify the types of metacognitive strategies employed by the high and low English proficiency secondary school students while reading academic text. Finally, this study also carries the purpose to investigate the differences (if any) in metacognitive strategies employed by the high and low English proficiency secondary school students.

In this study, the Metacognitive Awareness of Reading Strategies Inventory (MARSI) questionnaire was adapted (Mokhtari\&Reichard, 2002)in Section B of the questionnaire. The questionnaire consists of 30 items distributed into three subscales or factors which are Global Readings Strategies (GLOB) for item 1 to item 13, Problem-solving Strategies (PROB) for item 14 to 21 and Support Reading Strategies (SUP) for item 22 to item 30. The questionnaire was divided into three subscales or factors which are Global Readings Strategies (GLOB), Problem-solving Strategies (PROB) and Support Reading Strategies (SUP). The GLOB strategy consists of items that form part of intentional, carefully planned techniques that learners use to monitor or manage their reading. On the other hand, the PROB strategy consists of items that include actions and procedures readers use while working directly with the text. Finally, the SUP strategy consists of items involving basic support mechanism intended to improve readers' text comprehension.

The GLOB strategy consisted of items thatform part of intentional, carefully planned techniques that learners use to monitor or manage their reading. On the other hand, the PROB strategy consisted of items that include actions and procedures readers use while working directly with the text. Finally, the SUP strategy consisted of items involving basic support mechanism intended to improve readers' text comprehension. 
The questionnaire was divided into two sections which are Section A and Section B. Section A will be the background information of the respondents which consist of gender, PT3 assessment result for English and class. On the other hand, Section B was the questionnaire on the metacognitive strategies employed by the learners adapted from the Metacognitive Awareness of Reading Strategies Inventory (MARSI) questionnaire by Mokhtari and Reichard (2002).

\section{Findings and Discussion}

\section{Global Reading Strategies Employed by Secondary School Students}

Global Reading Strategies (GLOB) is the strategies that involved the setting stage for the reading act. Readers prepare themselves to read the reading material and find out about the overall view of the reading material.There are 13 items for Global Reading Strategies in the questionnaire and most of the students answered 'Always' for the sub categories of Global Reading Strategies. The result shows that the students are generally aware of the strategies and employed them while they are reading academic text in ESL classroom. In this study, 90 per cent of the students have purpose in mind when they read, yet, only 25 per cent of them employed this strategy almost all the time. 37.5 per cent of the students employed it for only 50 per cent of the time. Other than that, 80 per cent of the students think about what they know to help them understand what they read and majority of them employed this strategy almost all the time. 80 per cent of the students preview the reading material to see what the reading material is about before reading them, yet, only 22.5 per cent of them employed the strategy almost all the time.

Besides that, 27.5 per cent of the students usually think about whether the content of the reading fits their reading purpose while 35 percent of them sometimes employed the skimming strategy when reading academic text. Meanwhile, 42.5 per cent sometimes decided what to read closely and what to ignore when reading and only 17.5 per cent employed this strategy almost all the time. Other than that, 32.5 per cent of the students sometimes use their prior knowledge to help them in reading comprehension, while only 22.5 per cent of them employed this strategy almost all the time.

Moving on, 87.5 per cent of the students refer to certain words as clues to understand what they are reading and 25 per cent of them employed this strategy almost all the time. Besides that, 90 per cent of the students usually use typographical aids to identify the key information. Most of them usually employed this strategy, yet only 27.5 per cent of them employed this strategy almost all the time. 85 per cent of the students critically analyze and evaluate the information presented in the reading, but, most of them only employed this strategy 50 per cent of the time and only 12.5 per cent of them employed this strategy almost all the time. Other than that, 85 per cent of the students refer to tables, figures and pictures in academic text to increase their understanding. Other than that, 87.5 per cent of the students try to guess what the material is about when I read. Finally, 85 per cent of the students check to see if their guesses about the reading material are right or wrong.

Based on the result, it can be concluded that generally, the number of students who employed the strategies regularly are varied due to many factors. Some students may find the strategies are not applicable to their interest or they may not know what they should do in order to understand the academic text. Besides that, students might also feel that they only employ the metacognitive reading strategies whenever necessary, hence, the number of students who employed them almost all the time varied for every strategy. Generally, these students are aware of the metacognitive strategies that they employed when they are reading academic text. Students have purpose in mind probably because they are trained to read to answer comprehension questions.

Another possible reason for the overall results is that the students have the likelihood to refer to visual aids in order to make them understand the text better because reading requires a lot of focus compared to referring to visual aids. Besides that, students can see the whole picture of the text clearly when the text is accompanied by the visual aids such as tables, pictures and figures. Other than that, students also choose to refer to typographical aids such as "bold face" and "italics" because it attracts attention and carries certain meaning. The words with these types of typographical probably the major clues that will come out in the comprehension question or these words are probably the important vocabularies to understand in the future. 


\section{Problem-Solving Reading Strategies Employed by Secondary School Students}

Problem-Solving Reading Strategies (PROB) is the strategies that the readers use when they come across problems while reading. This enables readers to find out solution to overcome their problems. There are eight items in the questionnaire that belong to this category.

In this study, students mostly answered that they only employed Problem-Solving Reading Strategies about 50 per cent of the time. Besides that, 90 per cent of the students read slowly but carefully to be sure that they understand what they are reading. However, majority of them which is 45 per cent of the students only employed this 50 per cent of the time and only 22.5 per cent of them employed this strategy almost all the time. Other than that, 85 per cent of the students adjust their reading speed according to what they are reading and most of them which is 32.5 per cent of the students employed this strategy 50 per cent of the time as well. Meanwhile, 40 per cent from 85 per cent of the students stop from time to time to think about what they are reading and employed this strategy at 50 per cent of the time.

Meanwhile, 87.5 per cent of the students try to picture or visualize information to help them remember what they read. The majority of the students which is 32.5 per cent of them also employed this strategy 50 per cent of the time. Other than that, 85 per cent of the students re-read the reading material to increase their understanding when the reading material is difficult to understand. Most of the students which is 32.5 per cent of them employed this strategy always and almost all the time. In addition, 85 per cent of the students try to guess the meaning of the unknown words or phrases. Most of the students usually employed this strategy which is 30 per cent of them while 27.5 per cent of them employed this strategy almost all the time.

The result also shows that 92.5 per cent of the students try to get back on track when they lose concentration and 50 per cent of them employed this strategy 50 per cent of the time when they are reading academic text. Finally, 90 per cent of the students give more attention to what they are reading when the reading material is difficult to understand. Nonetheless, 45 per cent of them employed the strategy 50 per cent of the time and only 22.5 of them employed this strategy almost all the time.

Based on the overall result, it can be concluded that most of the students only employed the ProblemSolving Strategies 50 per cent of the time rather than all the time or almost all the time. This means that they are less aware of the Problem-Solving Strategies and need to employ the strategies more while reading academic text in order to increase their comprehension towards the reading material. The possible reason for this is the students probably do not know how to resolve the problem that they encounter when the reading material is hard to understand. Other than that, it is probably because they are lack of time to take any action to increase their understanding towards the reading material while reading academic text. Students may also feel that the strategies consume a lot of time such as they have to read slowly and stop to think about the reading material, so they preferred to do it only 50 per cent of the time.

Moreover, students may also understand the reading material most of the time so they are less likely to employ these strategies while reading. On the other hand, the students who answered that they never employ these strategies are probably the students who have no problems in understanding the reading material or the students who are not really keen on solving their problems while reading academic text.

\section{Support Reading Strategies Employed by Respondents}

Support Reading Strategies involved readers to use other initiatives to support their reading comprehension. Readers will carry out the support mechanisms such as using other reference materials and discussion to assist their understanding in reading. Assistance in reading is important for the students to ensure their understanding towards the reading material. There are nine items listed in this category in the questionnaire.

In this study, students mostly answered that they only employed Support Reading Strategies about 50 per cent of the time. In addition, 77.5 per cent or the students take notes while reading to help them understand what 
they read and majority of them which is 30 per cent employed this strategy 50 per cent of the time. Other than that, 80 per cent of the students underline or circle information in the text to help them remember the information and majority of them which is 27.5 per cent of the students usually employed this strategy. Moreover, 87.5 per cent of the students read aloud to help them understand what they read when the reading material is difficult to understand. Other than that, 90 per cent of them use reference materials such as dictionaries to help them understand what they read and 37.5 per cent of them which is the majority answered that they only employed this strategy 50 per cent of the time.

Besides that, 82.5 per cent of the students paraphrase the words in the reading material to help them better understand what they read and 35 per cent of them employed this strategy sometimes while 22.5 per cent of them employed this almost all the time. Next, 90 per cent of the students go back and forth in the reading material to find relationships among ideas in it and majority of them which is 32.5 per cent of them employed this strategy 50 per cent of the time.

Meanwhile, 77.5 per cent of the respondents ask themselves questions they like to have answered in the reading material and quite a number of them answered that they never employed this strategy which is 22.5 percent of them. Other than that, 85 per cent of the students summarize what they read to reflect on important information in the reading material and majority of them which is 30 per cent of them employed this strategy almost all the time. Finally, 90 per cent of the students discuss what they read with others to check their understanding and 35 per cent of them claimed that they always employed this strategy or almost all the time.

Based on the result, it can be concluded that the students are aware of the Support Reading Strategies while reading academic text. Most of them answered that they employed the strategies, although not all the time and majority of them answered that they sometimes employed the strategies. This is probably because Support Reading Strategies require time and effort to help the students in comprehending the reading material. Besides that, students may feel that they have to employ the strategies when necessary but not necessarily all the time. Moderate number of students employed the Support Reading Strategies occasionally, probably in the time that is convenient for them. This is because strategy such as reading aloud cannot be employed during examination and taking notes sometimes consume a lot more time than expected.

\section{Global Reading Strategies Employed by High English Proficiency Students}

The high English proficiency students are generally aware of the Problem Reading Strategies (PROB). Most of high English proficiency students do not answer never for this strategy. This is probably because they do employ the strategies while reading.

The students show high employment of the Global Reading Strategies where only 5 per cent of them answered 'Never' in the questionnaire for this category. Majority of them answered that they always employed the Global Reading Strategies. Most of the high English proficiency students always think about what they know to help them understand what they read. This is probably due to the fact that high English proficiency students have the tendency to know about the reading material and relate their prior knowledge to what they understand.

Besides that, none of the students claimed that they occasionally skim the reading material first to get the general idea, use typographical aid and refer to tables and picture included in reading material to help them understand the reading material. This is probably because they always skimming the reading material, referring to typographical aids and tables or figures to help them understand the reading material better instead of doing them occasionally.

\section{Problem-Solving Reading Strategies Employed by High English Proficiency Students}

The overall employment of Problem-Solving Reading Strategies by the high English proficiency students is high. This means that they are generally aware of these strategies. The students show high employment of the Problem-Solving Reading Strategies. In addition, majority of them answered that they always employed Problem- 
Solving Reading Strategies. Nonetheless, only 5 per cent of the students chose 'Never' in this section for items "I adjust my reading speed according to what I'm reading.", "I stop from time to time and think about what I'm reading." and "I try to picture or visualize information to help remember what I read."

In this study, most of the high English proficiency students re-read the reading material to increase their understanding when the reading material is difficult to understand. This is probably because they will feel that they can think while reading since they have high English proficiency. Other than that, 45 per cent of them answered that they also try to guess the meaning and pay more attention when reading to help them understand better. This is probably due to the fact that high English proficiency students have more attention span and give more effort in solving their problems.

\section{Support Reading Strategies Employed by High English Proficiency Students}

In general, the students are aware of the Support Reading Strategies as the overall result shows high mean for all strategies. The high English proficiency students also show high employment of the Support Reading Strategies.

The majority of them answered that they always employed the Support Reading Strategies. In this study, most of the high English proficiency students always employed the strategies to support their reading. Fifty per cent of them always use reference materials, summarize what they read and discuss what they read with others to better understand the reading material.

There are a moderate number of students who claimed that they employed the strategies occasionally, sometimes and usually. For instance, 35 per cent of the students answered that they usually underline or circle the information in the reading material to help them remember it. In addition, 30 per cent of them claimed that they read aloud 50 per cent of the time to help them understand better when the reading material becomes difficult.

Other than that, none of the students answered 'Never' for "I use reference materials such as dictionaries to help me understand what I read", "I go back and forth in the reading material to find relationships among ideas in it." and "I discuss what I read with others to check my understanding." This is probably because they always refer to dictionaries, reading back and forth to ensure understanding and discuss with their friends regularly to help them understand the reading material better.

Based on the results, it can be concluded that the high English proficiency students know how to employ the Support Reading Strategies while reading academic text. This is probably due to the fact that high English proficiency students have the tendency to take further action with extra effort for their reading comprehension.

\section{Global Reading Strategies Employed by Low English Proficiency Students}

In this study, the overall result indicates that the low English proficiency students are less likely to be aware of the strategies. Most of them answered 'Never' for the strategies. This shows that there is lack of awareness among the students of the Global Reading Strategies while reading academic text.

The students show low employment of the Global Reading Strategies where only few of them answered 'Always' in the questionnaire for this category. However, there are some of them answered that they never employed the Global Reading Strategies. Besides that, only a small number of the students claimed that they employed they Global Reading Strategies almost all the time or always employed them while reading academic text. Most of the low English proficiency students only employed the strategies 50 per cent of the time. 60 per cent of them mostly have purpose in mind and 65 per cent of them decide on what to ignore and what to focus on while reading. This is probably because low English proficiency students do not want to spend much time to read the reading material that they do not understand. Therefore, they employed the reading strategies when they think are necessary but not necessarily all the time. 
Most of the students also answered that they refer to the typographical aids, evaluate the information presented and check to see if their guesses about the reading material is right, yet, they only of this 50 per cent of the time. This is probably due to the fact that low English proficiency students have the tendency to use these clues to help them understand better since they do not understand the words alone.

Besides that, none of the students answered high employment for skimming and analyzing the reading material critically. This is probably because they do not always skimming the reading material or thinking critically to help them understand the reading material better.

\section{Problem-Solving Reading Strategies Employed by Low English Proficiency Students}

The overall result of the Problem-Solving Reading Strategies employed by low English proficiency students is low. Most of them answered 'Never' for the strategies. In this study, the students show low employment of the Problem-Solving Reading Strategies where only several them answered 'Always' in the questionnaire for this category. For instance, five per cent of the students always read slowly but carefully to be sure that they understand what they read while 20 per cent of them claimed that they never employ this strategy. Other than that, 5 per cent of the students always try to picture or visualize the information to help them remember what they read and 20 per cent of them never employ this strategy while reading academic text.

Quite a number of them answered that they never employed the Problem-Solving Reading Strategies. For example, 30 per cent of them answered that they never guess the meaning of unknown words or phrases to help them in reading comprehension. Most of the low English proficiency students only employed the strategies 50 per cent of the time. Sixty-five per cent of them stop from time to time to think about what they are reading to ensure that they understand what is being read and 75 per cent of them try to get back on track when they lose focus while reading.

Based on the result, it can be concluded that the low English proficiency students have low employment of Problem-Solving Reading Strategies. This is probably because low English proficiency students need to spend some time to better understand the reading material as they have slow pace of learning. Therefore, they feel taking actions could consume more time and it could disturb their train of thoughts. Other than that, they do not always adjust their reading speed due to time constraint or lack of vocabularies.

In addition, in this study, low English proficiency students rarely answered that they always employed the Problem-Solving Strategies while reading academic text or employed the strategies 75 per cent of the time. This is probably due to the fact that low English proficiency students have the tendency to not know what they should do in solving their problems.

\section{Support Reading Strategies Employed by Low English Proficiency Students}

Generally, the students are not aware of the Support Reading Strategies as most of them answered 'Never' for the strategies. Moreover, none of them answered ' 75 per cent' and 'Always' for several items which shows that they do not employed the strategies to support their reading.In this study, the students show low employment of the Problem-Solving Reading Strategies where only a few of them answered 'Always' in the questionnaire for this category. The majority of them answered that they never employed the Support Reading Strategies.

Other than that, quite a number of them answered that they never employed the Support Reading Strategies. For instance, 35 per cent of them answered that they never take notes while reading to help them in reading comprehension. This is probably due to the fact that low English proficiency students have the tendency to not neglect the importance of Support Reading Strategies.

In this study, most of the low English proficiency students only employed the strategies 50 per cent of the time. Sixty-five per cent of them use reference material such as dictionaries to help them understand what they read and 60 per cent of them read aloud to help them understand the reading material. This is probably because low English proficiency students lack of vocabularies to understand the material so they used the dictionary to find the 
meaning of unfamiliar words. Besides that, the low English proficiency students may find read aloud as a way that can help them focus on what they read. In addition, 55 per cent of them paraphrase the reading materials to better understand what they read. This is probably because they will feel it is easier for them to understand the idea in their own words.

Based on the results, it can be concluded that students do not always take action in Support Reading Strategies to help their understandings. This is probably they do not have time to do so. Besides, low English proficiency students do not always ask question while reading as they probably reading with specific purposes such as to answer comprehension question rather than to understand the whole text in general.

\section{Conclusion}

Based on this study, there are differences between metacognitive strategies employed in reading by the high and low English proficiency students. The high English proficiency students evidently employed metacognitive reading strategies more frequently compared to the low English proficiency students. They employed the strategies to help them understand better while reading academic text. Hence, reading strategies should be introduced and to be employed by the low English proficiency students to improve their comprehension while reading academic text in ESL classroom. It is shown that the students are generally aware of the metacognitive reading strategies and employ them from time to time. Therefore, it is possible to encourage the students to employ the strategies more often when reading the academic text for the improvement of their understanding toward the reading material.

As for the limitations of this study,it can be due to the time constraint. This is because if the time has been longer, other research methodology such as observation or interview can be carried out to support the findings better. Other than that, the number of the respondents are only enough to represent the population of Form 4 students in one school. Therefore, the results of this study cannot be used to generalize the whole population of Form 4 students. For future research, the number of respondents should be increased to get a high validity result of the study. In this study, the findings also show that high English proficiency students employed the metacognitive strategies more frequently compared to the low English proficiency students. Therefore, more study can be done to see whether other high and low English proficiency students from other schools give the same results.

\section{References}

[1] Al-Dawaidah, A. M., \& Al-Saadi, I. A. (2013). Assessing metacognitive awareness of reading strategy used for students from the Faculty of Education at the University of King Abdulaziz..Mevlana International Journal of Education (MIJE). Vol. 3(4), pp. 223-235.

[2] Anastasiou, D., \&Griva, E. (2009).Awareness of reading strategy use and reading comprehension among poor readers.Elementary Education Online, 8(2), 281-297.

[3] Anderson, N. J. (2002). The Role of Metacognition in Second Language Teaching and Learning.ERIC Digest.

[4] Block, E. (1986). The comprehension strategies of second language readers.TESOL Quarterly 20: 463-494.

[5] Block, E. (1992). See how they read: Comprehension monitoring of LI and L2 readers. TESOL Quarterly, 26, 319-343.

[6] Chamot, A. U. (2004). Issues in language learning strategy research and teaching.Electronic journal of foreign language teaching, 1(1), 14-26.

[7] Feng, X., \&Mokhtari, K. (1998).Reading easy and difficult texts in English and Chinese: Strategy use by native speakers of Chinese.Asian Journal of English Language Teaching, 8, 19-40.

[8] Flavell, J. H. 1979. Metacognition and cognitive monitoring: a new era of cognitive development enquiry. American Psychologist, 34 (10): 906-911.

[9] Gardner, R. (1987). Metacognitive and Reading Comprehension. Norwood. NJ:Ablex.

[10] Goodman, K. (1994). Reading, Writing and written texts: a transactional sociopsycholinguistic view. In R. Ruddell \& M. Rudde (Eds.).Theoretica Models And Process Of Reading, 4th ed. Newark, DE: International Reading.

[11] Grabe, W. (1991).Current developments in second language reading research.TESOLQuarterly, 25(3), 375-406.

[12] Hadavi, M. \&Hashemi, Z. (2014). Comparative analysis of vocabulary learning strategies in learning English as a Foreign Language among freshmen and senior Medical Sciences students across different fields of study. Malaysian Journal of ELT Research, 10(2), 19-33.

[13] Imtiaz, S. (2004). Metacognitive strategies of reading among esl learners. South Asian Language Review. Vol. XIV, No. $1 \& 2$. 
[14] Madhumathi, P., \& Ghosh, A. (2012).Awareness of reading strategy use of Indian ESL students and the relationship with reading comprehension achievement.CanadianCenter of Science and Education, Vol. 5, No. 12, 131-140.

[15] Mazumder, Q. H. (2010). Metacognition approaches to enhance student learning in mechanical engineering classroom. In Proceedings of the World Congress on Engineering (Vol. 2).

[16] Mokhtari, K., \&Reichard, C. (2002).Assessing students' metacognitive awareness of reading strategies.Journal of Educational Psychology, 94(2), 249-259.

[17] Mokhtari, K., \&Sheorey, R. (2002).Measuring ESL students' awareness of reading strategies.Journal of Developmental Education, 25, 2-10.

[18] Onovughe, G., \& Hannah, A. (2011).Assessing ESL students' awareness and application of metacognitive strategies in comprehending academic materials.Journal of Emerging Trends in Educational Research and Policy Studies, 2(5), 343-346.

[19] Oxford R. (1989).Variables affecting choice of language learning strategies by university students.The Modern Language Journal, (3):291-299.

[20] Oxford, R. (1990). Language Learning Strategies: What Every Teacher Should Know. Massachusetts: Heinle\&Heinle Publishers.

[21] Pani, S. (2004). Reading strategy instruction through mental modeling.ELT Journal, 58(4), 355-362.

[22] Paris, S.G., \& Jacobs, J. E. (1984).The benefits of informed instruction for children's reading awareness and comprehension skills. Child Development, 55, 2083-2093.

[23] Pressley, M. (2002).Metacognition and self-regulated instruction. In A. Farstrup\& S. Samuels (Eds.), What research has to say about reading instruction (3rd ed., pp. 291-309). Newark, DE: International Reading Association.

[24] Saemah Rahman \&Sa'diahKummin. 2010. The relationship between the use of metacognitive strategies and achievement in English. Abstrak International Conference on Learner Diversity (ICELD 2010), 57.

[25] Sheorey, R. \&Mokhtari, K. (2001).Differences in the metacognitive awareness of reading strategies among native and non-native readers.System: An International Journal of Educational Technology and Applied Linguistics, 29, 431-449.

[26] Stern, H. (1983). Fundamental Concepts of Language Teaching. Oxford: Oxford University Press.

[27] Stevenson, M., Schoonen, R. \&Glooper K. (2003).Inhibition or comprehension? A multidimensional comparison of reading processes in Dutch and English. Language learning, 53 (4), 765-815.

[28] Wenden, A. (1991). Learner Strategies for Learner Autonomy. Hemel Hempstead: Prentice Hall.

[29] Yau, J. L. C. (2009). Reading characteristics of Chinese- English adolescents: Knowledge and application of strategic reading.Metacognition Learning, 4, 217-235. 